\title{
CORRIGENDUM
}

\section{A genome-wide analysis of putative functional and exonic variation associated with extremely high intelligence}

SL Spain, I Pedroso, N Kadeva, MB Miller, WG lacono, M McGue, E Stergiakouli, GD Smith, M Putallaz, D Lubinski, EL Meaburn, R Plomin and MA Simpson

Molecular Psychiatry (2016) 21, 1152; doi:10.1038/mp.2015.145; published online 1 September 2015

Correction to: Molecular Psychiatry advance online publication, 4 August 2015; doi:10.1038/mp.2015.108
Following publication of this paper, the authors noticed that the eighth author's name was presented incorrectly. The author's name should have been listed as G Davey Smith. 